\title{
IDENTIFICATION OF CRITICAL COMPONENTS OF RESILIENCE DURING AND AFTER ECONOMIC CRISES: THE CASE OF WOMEN FOOD OPERATORS IN KUALA LUMPUR
}

\author{
Nazatul Shima Abdul Rani1*, K. Sarojani Krishnan, ${ }^{1}$ Zurinah Suradi ${ }^{2}$, \\ and Nurita Juhdi ${ }^{3}$ \\ ${ }^{1}$ Universiti Kuala Lumpur Business School, Wisma Yayasan Selangor, \\ No. 74, Jalan Raja Muda Aziz, Kampung Baru, 50300 Kuala Lumpur, Malaysia \\ ${ }^{2}$ College of Commerce and Business Administration, Dhofar University, \\ P.O.Box 2509, 211 Salalah, Sultanate of Oman \\ ${ }^{3}$ Kulliyah of Economics and Management Sciences, International Islamic University Malaysia, \\ P.O. Box 10,50728 Kuala Lumpur, Malaysia \\ *Corresponding author: shima.rani@unikl.edu.my
}

Published online: 25 October 2019

To cite this article: Abdul Rani, N.S., Krishnan, K.S., Suradi, Z., and Juhdi, N. (2019). Identification of critical components of resilience during and after economic crises: The case of women food operators in Kuala Lumpur. Asian Academy of Management Journal, 24(Supp. 2), 111-126. https://doi.org/10.21315/aamj2019.24.s2.8

To link to this article: https://doi.org/10.21315/aamj2019.24.s2.8

\section{CORRIGENDUM}

Reason: Inclusion of research grant number in the Acknowledgements.

\section{ACKNOWLEDGEMENTS}

Sincere appreciation to Fundamental Research Grant Scheme (FRGS) for the grant awarded to produce this research, and this is part of a huge research project.

\section{Corrected version:}

\section{ACKNOWLEDGEMENTS}

Sincere appreciation to Fundamental Research Grant Scheme (FRGS) granted to fund this study by Ministry of Higher Education Malaysia (MOHE) with reference FRGS/1/2017/SS03/UNIKL/02/4.

(C) Asian Academy of Management and Penerbit Universiti Sains Malaysia, 2021. This work is licensed under the terms of the Creative Commons Attribution (CC BY) (http://creativecommons.org/licenses/by/4.0/). 


\title{
IDENTIFICATION OF CRITICAL COMPONENTS OF RESILIENCE DURING AND AFTER ECONOMIC CRISES: THE CASE OF WOMEN FOOD OPERATORS IN KUALA LUMPUR
}

\author{
Nazatul Shima Abdul Rani ${ }^{1 *}$, K. Sarojani Krishnan, ${ }^{1}$ Zurinah Suradi ${ }^{2}$, \\ and Nurita Juhdi $^{3}$ \\ ${ }^{1}$ Universiti Kuala Lumpur Business School, Wisma Yayasan Selangor, \\ No. 74, Jalan Raja Muda Aziz, \\ Kampung Baru, 50300 Kuala Lumpur, Malaysia \\ ${ }^{2}$ College of Commerce and Business Administration, Dhofar University, \\ P.O.Box 2509, 211 Salalah, Sultanate of Oman \\ ${ }^{3}$ Kulliyah of Economics and Management Sciences, \\ International Islamic University Malaysia, P.O. Box 10, \\ 50728 Kuala Lumpur, Malaysia \\ *Corresponding author: shima.rani@unikl.edu.my
}

Published online: 25 October 2019

To cite this article: Abdul Rani, N.S., Krishnan, K.S., Suradi, Z., and Juhdi, N. (2019). Identification of critical components of resilience during and after economic crises: The case of women food operators in Kuala Lumpur. Asian Academy of Management Journal, 24(Supp. 2), 111-126. https://doi.org/10.21315/aamj2019.24.s2.8

To link to this article: https://doi.org/10.21315/aamj2019.24.s2.8

\begin{abstract}
In the past, there has been a preponderance of studies on entrepreneurs or small and medium enterprises (SMEs) in Malaysia; however, very few studies concentrated on women entrepreneurs. Women entrepreneurs are known to be persistent and resilient in running their business. However, it may be interesting to focus on factors or components that contribute towards their resiliency. Hence, this study explores the critical components of entrepreneurial resiliency which play a significant role in the business survival of women entrepreneurs during and after undergoing economic crises. The term resilience comprises three components, namely hardiness, resourcefulness, and optimism. Hardiness refers to adaptive capacity, and not easily discouraged by failures. Resourcefulness, on the other hand, relates to cash flow, investment, relational networks, material assets, and the ability to adapt to changes, while optimism means the preparedness to make decisions, take action, and the ability to see the humorous side of things. The sample of the study consisted
\end{abstract}

(C) Asian Academy of Management and Penerbit Universiti Sains Malaysia, 2019. This work is licensed under the terms of the Creative Commons Attribution (CC BY) (http://creativecommons. org/licenses/by/4.0/). 
of 100 women entrepreneurs, mainly food operators in Klang Valley who were selected randomly. Most of the women entrepreneurs were aged above 30 years, and more than half have more than 10 years' experience in running their business. A set of questionnaire with items on entrepreneurial resilience and its components-hardiness, resourcefulness, and optimism - was used to gain information among women entrepreneurs. The findings show that the most critical components for resilience during crises was resourcefulness, while optimism emerged as the most important component after undergoing crises.

Keywords: resilience, women entrepreneurs, hardiness, resourcefulness, optimism

\section{INTRODUCTION}

Small and medium enterprises (SMEs) play an important role in the Malaysian economic growth and rapid industrial development towards achieving the objectives of the Eleventh Malaysia Plan. SMEs act as a player and backbone of industrial development in the economy of Malaysia, whereby $98.5 \%$ establishments and 59\% employment are derived from SMEs in 2015 (Eleventh Malaysia Plan 2016-2020, 2015). The Malaysian government has always been giving strong support towards the expansion and sustainability of SME activities; nevertheless, it is surprising that the attrition faced by SMEs is still high. Previous studies have been conducted on entrepreneur resilience (Weick \& Sutcliffe, 2001; Gunasekaran, Bharatendra \& Griffin, 2011; Bhamra, Dani \& Burnard, 2011; Ayala \& Manzano, 2014); however, research carried out on women entrepreneurs or SMEs are surprisingly scarce. The Malaysian government has rendered a lot of support to improve the performance of SMEs. Research works conducted in this area have mostly focused on lack of resources or support towards SMEs (Coyte, Ricerri \& Guthrie, 2012; Dassi, Iborra \& Safon, 2015; Kundu \& Katz, 2003; Muscio, 2007). However, the provision of financial support alone is deemed inadequate to further strengthen the performance of SMEs in Malaysia, and the implementation of the Goods and Services Tax (GST) led to a few SME operators to commit suicide due to fines imposed on them for non-compliance as well as other reasons such as reduction of profits (The Malay Mail Online, 11 May 2015; 1 June 2015). Hence, the purpose of this study is to identify the critical components of resilience possessed by women entrepreneurs in order to sustain their business operations during crises and recovery.

The research objectives are as follows:

1. To investigate the critical components of resilience for business sustainability among women food operators in Klang Valley during the economic crises. 
2. To investigate the critical components of resilience for business sustainability among women food operators in Klang Valley after the economic crises.

Research questions:

1. What are the critical components of resilience for business sustainability among women food operators in Klang Valley during the economic crises?

2. What are the critical components of resilience for business sustainability among women food operators in Klang Valley after the economic crises?

\section{LITERATURE REVIEW}

This section discusses the overview of women entrepreneurs in Malaysia, economic cycle, and also resilience as a factor for business survival.

\section{Overview of Women Entrepreneurs in Malaysia}

Despite the increasing number of female graduates, the number of women entrepreneurs are still far lower than male entrepreneurs. Each year, the number of women graduates entering institutions of higher learning is high as compared to their counterparts. These scenarios have been on-going for quite some time (Yusof, Alias \& Habil, 2012). According to the Department of Statistics, in the year 2016, the female labour participation rate was $54.3 \%$, which translated into $54 \%$ of the labour force for every 100 women. If this percentage is compared to the percentage of female student intake by public institutions of higher learning, that was $68 \%$ in $2013 / 14$, there was still about $14 \%$ of educated and professional women who did not enter the labour market. Hence, it is vital that women who are educated and classified as professionals be involved in entrepreneurship and one way to encourage this is via economic empowerment.

In Malaysia, women have been involved in the entrepreneurship field for many decades. More recently, it has been illustrated that women entrepreneurs have become increasingly important in the entrepreneurship segment in Malaysia. Various types of programs and activities have been organised by a number of agencies to promote and improve the rate of participation of women entrepreneurs in the entrepreneurship sector. Subsequently, women entrepreneurs have made a great contribution towards the economic development of Malaysia (Alam, Jani \& Omar, 2011). According to Kang (2016), government agencies and 
programmes have been established to assist women entrepreneurs including those from Secretariat for Advancement of Malaysian Entrepreneurs (SAME)'s women talentship initiative, SME Corporation's Skills Upgrading Programme, and Malaysia External Trade Development Corporation (MATRADE)'s Women Exporters Development Programme. Moreover, more programmes and training have been organised to empower women entrepreneurs especially single mothers, housewives, and women in the category of B40, the lowest income group.

Besides, according to Datuk Seri Rohani Abdul Karim, the former Women, Family and Community Development Minister, about RM200 million has been allocated for Amanah Ikhtiar Malaysia to provide micro-credit facility to women entrepreneurs in Malaysia as announced by the Prime Minister during the 2018 Budget tabling (The Star Online, 29 October 2017). The advantage of becoming a business owner is to help women escape from the poverty trap. Thus, it cannot be denied that the incentives created for women entrepreneurs are huge, and most women entrepreneurs venture into business due to economic reasons.

\section{Theory of Resilience and Entrepreneur}

Holling (1973) coined the word "resilience" in the study of ecology, where he defines resilience as the measurement of "persistence" in a system that absorbs change and disturbance but still persists after all the changes and disturbances have occured. In other words, the system is considered stable when it is able to return to an equilibrium state after temporary disturbance; hence the faster it returns with the least fluctuation, it is considered more stable.

Thus, the Resilience Theory discusses the impact of challenging events on individuals and how well individuals adapt to the changes or traumatic experiences, and later return to an equilibrium state or recover from any setback (Ayala \& Manzano, 2014; Gunderson, 2000; Zautra, Hall \& Murray, 2010). Hence, one of the key traits of entrepreneurs is resilience. Entrepreneurial resilience may include forming networks, accepting that changes are normal, and avoiding crises as much as possible.

The definition of resilience by Zautra, Hall and Murray (2010) states that it is a by-product of individuals' interactions with the environment, and the processes that either promote their well-being or protect themselves from overcoming risky situations. To be a sustainable and successful entrepreneur, resilience capacity is required to overcome critical situations that emerge from failures and crises faced previously (Duchek, 2018; Gunasekaran, Bharatendra \& Griffin, 2011). 
Entrepreneur resilience includes hardiness, resourcefulness, and optimism (Asgary, Azimi \& Anjum, 2013; Bhamra, Dani \& Burnard, 2011). Hardiness refers to the adaptive capacity such as the ability to change in response to new pressure. Resourcefulness is described as cash flow, investment finance, relational networks, and material assets (Torstensson \& Pal, 2013). Optimism is the preparedness of entrepreneurs to make decisions and take actions to reduce vulnerability and the impact of facing disaster (Weick \& Sutcliffe, 2001). All these three components, namely resourcefulness, optimism, and hardiness make up the composite factor of resilience. Thus, this study aims to identify the most critical component(s) during and after economic crises for women food operators. This is crucial because the findings can be used as a guide for future women food operators in sustaining their business operations.

\section{Economic Cycle and Impact to Businesses}

The economic cycle is divided into five phases which include the recovery phase, early upswing phase, late upswing phase, slow economy or initial recession phase, and finally, the recession phase. The first phase, the recovery phase is characterised by stimulating the economic policy or fiscal policy, followed by the increase in confidence level of investors and entrepreneurs, while the rate of inflation rate decreases. Normally, the policy is more about expansionary policy such as reducing tax, lowering interest rate of banks, and encouraging spending by the public. The second phase is the early upswing phase whereby the confidence level of investors and businessmen increases, and there is healthy economic growth while inflation remains low. The third phase is the late upswing phase which is characterised by mentality boom whereby the investors' confidence level is progressing very high. Moreover, the inflation rate becomes high due to high employability and higher spending power of the public. As such, the policy becomes more restrictive to reduce the spending power among the public. The fourth phase is economic slowdown or initial recession which is characterised by a sudden drop of confidence level among investors and businessmen due to the high inflation rate and therefore, inventory correction begins. Finally, the recession phase is reflected by the weak confidence level among investors and businessmen, very high inflation rate, and significant reduction in production due to high operational or production costs (Fischer, 2016; Dustmann, Glitz \& Vogel, 2010). This study investigates resilience strategies adopted by women food operations during (recession phase in the economic cycle) and after the economy crises (recovery phase in the economic cycle) to sustain their business operations. 


\section{METHODOLOGY}

\section{Sampling and Data Collection}

A set of questionnaire was distributed to 100 women food operators selected randomly in areas around Kuala Lumpur including Kampung Baru. The questionnaire was divided into two parts. Part A comprises questions on respondent profiles, and Part B comprises items on each of the components of resilience, namely resourcefulness, optimism, and hardiness. There are three columns provided for responses by the sample. The first column indicates responses during the economic crises (recession phase), while the third column indicates responses after the economic crises (recovery phase) (Likert scale: 5 - Strongly Agree while 1 - Strongly Disagree). The second column refers to the items on each factor of resilience. The data collection was done over a period of two months from October to November 2017.

\section{Respondent Profiles}

Most of the samples were business owners aged above 30 years (89\%), while the rest were under 30 years of age. About $63 \%$ of the business owners have been running their business for more than 10 years, while the remaining owners had less. In terms of education background, about $60 \%$ of the proprietors of the business were educated up to the secondary level, $25 \%$ with a diploma, $7 \%$ with a bachelor's degree, and $8 \%$ with a master's degree or $\mathrm{PhD}$. Most of the respondents were sole proprietors (85\%), 10\% owned businesses based on partnership, and $5 \%$ had private limited businesses. Only $5 \%$ of the respondents had at least five employees, $75 \%$ with around 6 to 10 employees, and $20 \%$ employed about 20 employees. Correlation analysis between loans received and business performance or profits shows that there is no significant relationship. However, there is a significant relationship between those who earned profits in 2016 and 2017 as shown in Table 1. 
Table 1

Pearson correlation values for loans and profit

\begin{tabular}{llccc}
\hline & & Loan & Profit 2016 & Profit 2017 \\
\hline Loan & Pearson correlation & 1 & -0.014 & 0.156 \\
& Sig. (2-tailed) & & 0.887 & 0.121 \\
\multirow{3}{*}{ Profit 2016 } & N & 100 & 100 & 100 \\
& Pearson correlation & -0.014 & 1 & $\mathbf{0 . 2 5 3}^{*}$ \\
& Sig. (2-tailed) & 0.887 & & 0.011 \\
& N & 100 & 100 & $\mathbf{1 0 0}$ \\
& Pearson correlation 2017 & 0.156 & $\mathbf{0 . 2 5 3}^{*}$ & 1 \\
& Sig. (2-tailed) & 0.121 & $\mathbf{0 . 0 1 1}$ & \\
& N & 100 & $\mathbf{1 0 0}$ & 100 \\
\hline
\end{tabular}

${ }^{*}$ Correlation is significant at the 0.05 level (2-tailed)

\section{RESULTS AND DISCUSSION}

\section{Descriptive Analysis}

In this study, descriptive analysis was conducted and the results are shown in the following tables. The findings are described in the discussion section.

\section{Comparing Means between Hardiness, Optimism, and Resourcefulness}

The findings as shown in Table 2 below indicate that most of the women entrepreneurs agreed that during crises, the most important component of resilience is resourcefulness $($ Mean $=4.06$; s.d. $=0.30)$, followed by hardiness $($ Mean $=4.04$; s.d. $=0.20)$, and optimism $($ Mean $=3.99$; s.d. $=0.18)$. After crises, it shows that most of the women entrepreneurs agreed that the most important component for resilience is optimism (Mean $=4.40$; s.d. $=0.18$ ), followed by resourceful $($ Mean $=4.07$; s.d. $=0.23)$, and finally, hardiness $($ Mean $=3.99$; s.d. $=0.21)$.

Table 2

Means comparison: Hardiness, optimism, resourcefulness

\begin{tabular}{|c|c|c|c|c|c|c|}
\hline & \multicolumn{2}{|c|}{ Hardiness } & \multicolumn{2}{|c|}{ Optimism } & \multicolumn{2}{|c|}{ Resourcefulness } \\
\hline & Mean & s.d. & Mean & s.d. & Mean & s.d. \\
\hline During crises & 4.04 & 0.20 & 3.99 & 0.18 & 4.06 & 0.30 \\
\hline After crises & 3.99 & 0.21 & 4.40 & 0.18 & 4.07 & 0.23 \\
\hline
\end{tabular}




\section{Important Items on Hardiness (Resilience) During and After Crises}

\section{Adaptive capacity}

Most of the women food operators agreed that the most important items for adaptive capacity during crises are feedback from customers (Mean $=4.36$; s.d. $=0.60)$, feedback from employees $($ Mean $=4.22$; s.d. $=0.68)$, meeting customers' expectation (Mean $=4.17$; s.d. $=0.65)$, and feedback as a way to improve business (Mean $=4.00$; s.d. $=0.68$ ). Whereas, after crises the most important items for adaptive capacity are feedback as valuable input $($ Mean $=4.20$; s.d. $=0.60)$, feedback from employees $($ Mean $=4.09$; s.d. $=0.62)$, accepting changes and improving business operation $($ Mean $=4.06$; s.d. $=0.72$ ), feedback to improve business (Mean $=4.03$; s.d. $=0.70)$, and meeting customers' expectations $($ Mean $=4.02$; s.d. $=0.68)$. Refer to Table 3 .

Table 3

Item statistics for adaptive capacity (hardiness)

\begin{tabular}{lccccccccc}
\hline & \multicolumn{3}{c}{ During crises } & & \multicolumn{3}{c}{ After crises } \\
\cline { 2 - 3 } & Mean & s.d. & $\mathrm{N}$ & & Mean & s.d. & $\mathrm{N}$ \\
\hline Accept changes and improve my business & 3.54 & 0.89 & 100 & & $\mathbf{4 . 0 6}$ & & 0.72 & 100 \\
Meet customer expectations & $\mathbf{4 . 1 7}$ & 0.65 & 100 & & $\mathbf{4 . 0 2}$ & 0.68 & 100 \\
Feedback from customers & $\mathbf{4 . 3 6}$ & 0.60 & 100 & & 3.99 & 0.72 & 100 \\
Feedback as a way to improve my business & $\mathbf{4 . 0 0}$ & 0.68 & 100 & & $\mathbf{4 . 0 3}$ & 0.70 & 100 \\
Accept feedback from employees & $\mathbf{4 . 2 2}$ & 0.68 & 100 & & $\mathbf{4 . 0 9}$ & 0.62 & 100 \\
Accept feedback as valuable input & 3.81 & 0.73 & 100 & & $\mathbf{4 . 2 0}$ & 0.60 & 100 \\
Accept feedback from suppliers & 3.80 & 0.82 & 100 & & 3.99 & & 0.70 & 100 \\
\hline
\end{tabular}

\section{Not easily discouraged from failures}

Most of the women food operators agreed that during crises, they are willing to accept customers during rainy days $($ Mean $=4.63$; s.d. $=0.56)$, accept customers during public holidays $($ Mean $=4.29$; s.d. $=0.52)$, and accept losses $($ Mean = 4.27; s.d. $=0.68)$. After crises most of the women food operators agreed that they are willing to accept low income $($ Mean $=4.03$; s.d. $=0.86)$. Refer to Table 4. 
Table 4

Items statistics for not easily discouraged (hardiness)

\begin{tabular}{lcccccccc}
\hline & \multicolumn{3}{c}{ During crises } & & \multicolumn{3}{c}{ After crises } \\
\cline { 2 - 3 } & Mean & s.d. & N & & Mean & s.d. & N \\
\hline Accept low income & 3.40 & 0.95 & 100 & & $\mathbf{4 . 0 3}$ & 0.86 & 100 \\
Accept losses & $\mathbf{4 . 2 7}$ & 0.68 & 100 & & 3.91 & 0.78 & 100 \\
Accept customers although it is raining & $\mathbf{4 . 6 3}$ & 0.56 & 100 & & 3.82 & 0.76 & 100 \\
Accept customers although it is hot & & 3.99 & 0.58 & 100 & & 3.84 & 0.81 & 100 \\
Accept customers during public holidays & $\mathbf{4 . 2 9}$ & 0.52 & 100 & & 3.95 & & 0.87 & 100 \\
\hline
\end{tabular}

Important items on optimism (resilience) during and after crises

\section{Decision making-optimism (resilience) during recovery}

During crises, most of the women food operators agreed that they have to consider long-term effects to the business in making decisions $($ Mean $=4.17$; s.d. $=0.59)$, have to make quick decisions for long-term solutions (Mean $=4.17$; s.d. $=0.64$ ), must be able to make quick decisions (Mean $=4.09$; s.d. $=0.53$ ), and also should be able to make quick decisions for routine tasks $($ Mean $=4.05$; s.d. $=0.72)$. However, after crises, most the women entrepreneurs agreed that it is important for them to make decisions in a stable environment $($ Mean $=4.34$; s.d. $=0.59)$, consider longterm effects to the business when making decisions $($ Mean $=4.26$; s.d. $=0.691)$, able to make quick decisions (Mean $=4.15$; s.d. $=0.64$ ), and make quick decisions for long-term solutions $($ Mean $=4.14$; s.d. $=0.55)$. Refer to Table 5 .

Table 5

Item statistics on prepared to make decisions (optimism)

\begin{tabular}{lccccccccc}
\hline & \multicolumn{3}{c}{ During crises } & & & \multicolumn{3}{c}{ After crises } \\
\cline { 2 - 3 } & Mean & s.d. & & & & Mean & & s.d. & N \\
\hline Think before making any decisions & 3.78 & 0.69 & 100 & & 3.96 & & 0.97 & 100 \\
Make quick decisions & $\mathbf{4 . 0 9}$ & 0.53 & 100 & & $\mathbf{4 . 1 5}$ & & 0.64 & 100 \\
Make decisions in a stable environment & 3.93 & 0.67 & 100 & & $\mathbf{4 . 3 4}$ & 0.590 & 100 \\
Make quick decisions for routine tasks & $\mathbf{4 . 0 5}$ & 0.72 & 100 & & 3.99 & 0.80 & 100 \\
Make quick decisions for long-term solutions & $\mathbf{4 . 1 7}$ & 0.64 & 100 & & $\mathbf{4 . 1 4}$ & & 0.55 & 100 \\
Consider long-term effects to the business & $\mathbf{4 . 1 7}$ & 0.59 & 100 & & $\mathbf{4 . 2 6}$ & & 0.69 & 100 \\
when making decisions & & & & & & \\
\hline
\end{tabular}




\section{Important items on optimism}

From Table 6, the most important element during crises is to receive many customers for business survival $($ Mean $=4.10$; s.d. $=0.75$ ), and after crises the most important trait is being confident to be in business with a small profit $($ Mean $=4.36$; s.d. $=0.628)$, confident in receiving many customers $($ Mean $=4.22$; s.d. $=0.73)$, confident with their business $($ Mean $=4.12$; s.d. $=0.64)$, confident in accepting orders anytime (Mean $=4.12$; s.d. $=0.77$ ), will be in business although experiencing losses $($ Mean $=4.06$; s.d. $=0.71)$, and finally, confident to be in business although cheated by employees $($ Mean $=4.00$; s.d. $=0.91)$. Refer to Table 6 .

Table 6

Item statistics on preparedness to take action (optimism)

\begin{tabular}{|c|c|c|c|c|c|c|}
\hline & \multicolumn{3}{|c|}{ During crises } & \multicolumn{3}{|c|}{ After crises } \\
\hline & Mean & s.d. & $\mathrm{N}$ & Mean & s.d. & $\mathrm{N}$ \\
\hline In business forever & 3.94 & 0.87 & 100 & 3.98 & 0.75 & 100 \\
\hline In business although experiencing losses & 3.96 & 0.82 & 100 & 4.06 & 0.71 & 100 \\
\hline $\begin{array}{l}\text { Confident to be in business although cheated } \\
\text { by employees }\end{array}$ & 3.98 & 0.75 & 100 & 4.00 & 0.91 & 100 \\
\hline In business although cheated by customers & 3.79 & 0.84 & 100 & 3.94 & 0.71 & 100 \\
\hline Accept orders anytime & 3.96 & 0.85 & 100 & 4.12 & 0.77 & 100 \\
\hline Confident to receive many bookings & 3.98 & 0.84 & 100 & 3.90 & 0.77 & 100 \\
\hline Confident to receive many customers & 4.10 & 0.75 & 100 & 4.22 & 0.73 & 100 \\
\hline Confident to be in business with a small profit & 3.97 & 0.81 & 100 & 4.36 & 0.63 & 100 \\
\hline Confident with this business & 3.92 & 0.73 & 100 & 4.12 & 0.64 & 100 \\
\hline
\end{tabular}

\section{Resourcefulness}

The findings in Table 7 shows the most important items related to resourcefulness during the crises which include controlling resources (Mean = 4.22 ; s.d. $=0.71)$, maintaining quality of products and services $($ Mean $=4.17$; s.d. $=0.60)$, solving problems on resources independently $($ Mean $=4.07$; s.d. $=$ 0.66 ), controlling human resources (Mean $=4.06$; s.d. $=0.75$ ), controlling products and services (Mean $=4.05$; s.d. $=0.74$ ), and deciding on resources needed (Mean $=3.84$; s.d. $=0.86$ ). However, after crises, most of the women entrepreneurs agreed that the most important element is the ability to control resources (Mean $=4.19$; s.d. $=0.83)$, deciding on resources needed for the business (Mean = 4.13; s.d. $=0.69)$, solving problems on resources independently, $($ Mean $=4.11$; s.d. $=$ $0.67)$, maintaining quality of products and services (Mean $=4.11$; s.d. $=0.79)$, and controlling products and services $($ Mean $=4.06$; s.d. $=0.66$ ). 
Table 7

Item statistics on resourcefulness

\begin{tabular}{|c|c|c|c|c|c|c|}
\hline & \multicolumn{3}{|c|}{ During crises } & \multicolumn{3}{|c|}{ After crises } \\
\hline & Mean & s.d. & $\mathrm{N}$ & Mean & s.d. & $\mathrm{N}$ \\
\hline Decide on resources needed for my business & 3.84 & 0.86 & 100 & 4.13 & 0.69 & 100 \\
\hline Solve problems on resources independently & 4.07 & 0.66 & 100 & 4.11 & 0.66 & 100 \\
\hline Control resources well in my business & 4.22 & 0.71 & 100 & 4.19 & 0.83 & 100 \\
\hline Control human resources well for my business & 4.06 & 0.75 & 100 & 3.81 & 0.71 & 100 \\
\hline Maintain quality of products and services & 4.17 & 0.60 & 100 & 4.11 & 0.79 & 100 \\
\hline $\begin{array}{l}\text { Control products and services well for my } \\
\text { business }\end{array}$ & 4.05 & 0.74 & 100 & 4.06 & 0.66 & 100 \\
\hline
\end{tabular}

\section{DISCUSSION}

This study highlights that the most important component of resilience during crises for women food operators is resourcefulness. Figure 1 summarises the findings of this research. The findings support previous research on components that are critical during crises which include the ability to find alternative resources to ensure that the business will be able to face turbulence and bounce back from disruption (Dahles \& Susilowati, 2015; Williams \& Vorley, 2014).

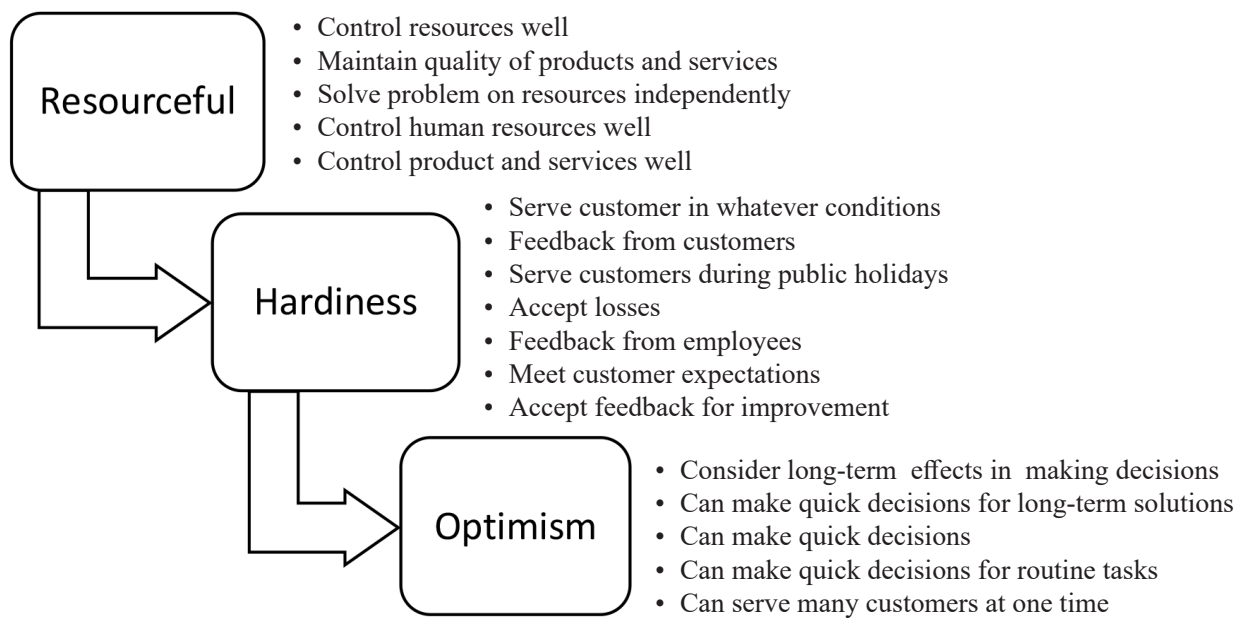

Figure 1. Important components of resilience during crises 
However, the most important components of resilience after crises for women food operators include being optimistic, resourceful, and hardiness as shown in Figure 2. The findings that optimism and resourcefulness are the most critical components for resilience after crises support earlier studies by McInnis-Bowers, Parris and Galperin (2017), and Ayala and Manzano (2014). Hence, it is highly critical for women food operators to be optimistic about their business venture after crises. They are willing to run their business although they may obtain small profits, able to make decisions in a more stable environment, always consider long-term effects in making decisions, willing to serve many customers at one time, able to make quick decisions for long-term solutions, able to take orders anytime, and will operate the business although they are facing losses or are cheated by employees. It can be concluded that being resourceful is one of the most important components of resilience to ensure business sustainability during crises, and the second most important component after crises (McInnis-Bowers, Parris \& Galperin, 2017; Ayala \& Manzano, 2014; Nandamuri, 2013).

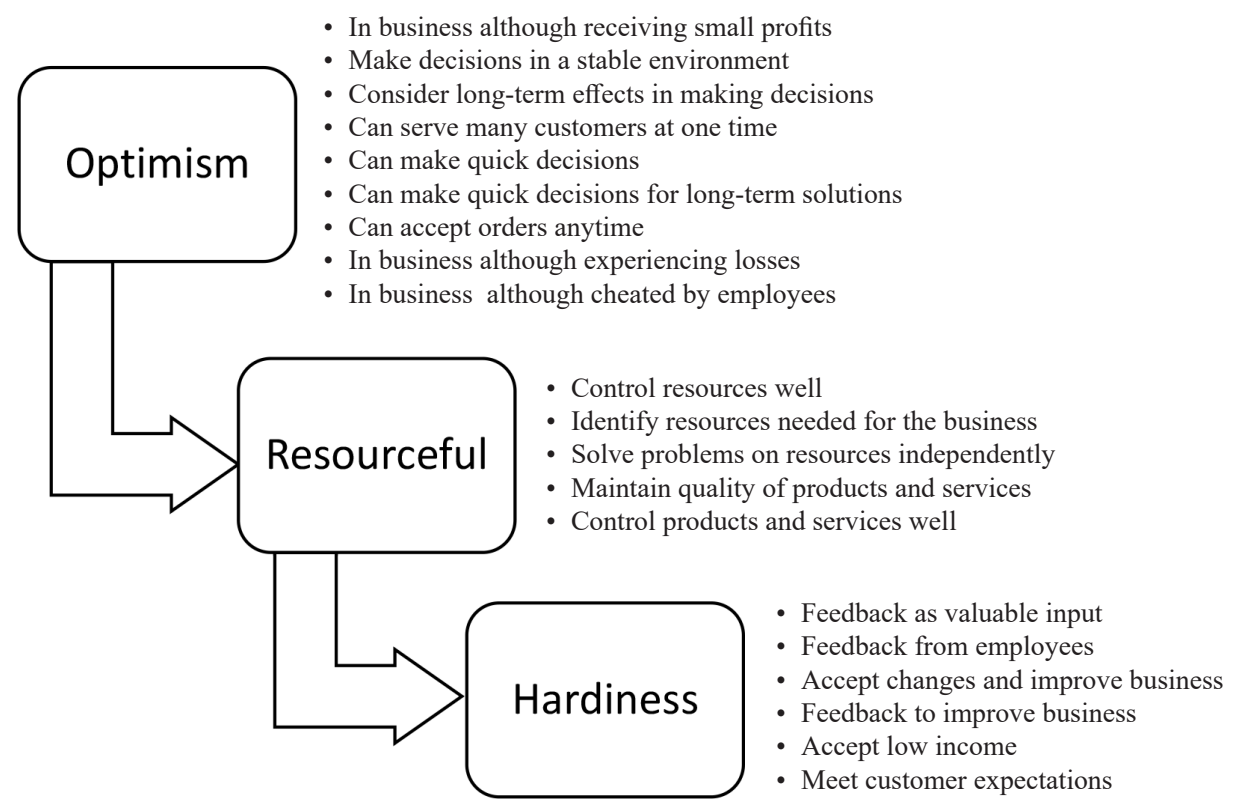

Figure 2. Important components of resilience after crises 


\section{IMPLICATIONS AND RECOMMENDATIONS}

The study has implications to existing and potential women entrepreneurs to adopt the characteristics/traits necessary, that is, resourcefulness and optimism for survival of business especially during and after crises instead of giving up altogether when their profits decrease. In this study, the findings show that hardiness is not an important component. However, efforts by the relevant authorities should be made by providing training to new women entrepreneurs by equipping them with the relevant skills and knowledge on how to be resilient by adopting characteristics/ traits such as resourcefulness, optimism, and hardiness. By possessing the three characteristics as reflected in the components, the extent to which they may become resilient in times of hardship may increase. Thus, entrepreneurs may have a higher probability of succeeding in their business during and after crises by incorporating new marketing strategies in accordance with the situation faced. The study is also important as successful women entrepreneurs would mean that they would contribute effectively towards the gross national income, hence raising the productivity of the nation. It is recommended that further research concentrates on other exemplary successful women entrepreneurs and comparisons be made with the traits possessed by less successful women entrepreneurs to identify the missing traits so that appropriate training can de designed to help more women entrepreneur.

\section{CONCLUSION}

The findings of the study suggest that during crises, women entrepreneurs claimed that being resourceful was the most critical component that helped them to be resilient to sustain their business. In other words, they were able to control resources well, with ample resources to maintain quality products and services, and also control human resources well in ensuring business survival. These findings are quite similar to the research conducted by Ayala and Manzano (2014) who found that being resourceful was the most critical factor for entrepreneurs.

On the other hand, being optimistic about their business emerged as the most important factor that kept women entrepreneurs confident to strive hard in their business. This means that they had the ability to be prepared mentally to make the right decisions and further take the most appropriate actions in combating the impact of disaster faced during crises. Thus, this finding also supports earlier research conducted by Ayala and Manzano (2014) who found that women or female entrepreneurs were more optimistic than male entrepreneurs. 
Nevertheless, being resourceful is still the second most important characteristic that they need to have to ensure success in their business. Hence, being resourceful emerges as an important component during and after crises for women entrepreneurs to be resilient towards business survival.

\section{ACKNOWLEDGEMENTS}

Sincere appreciation to Fundamental Research Grant Scheme (FRGS) for the grant awarded to produce this research, and this is part of a huge research project.

\section{REFERENCES}

Alam, S.S., Jani, M.F.M., \& Omar, N.A. (2011). An empirical study of success factors of women entrepreneurs in southern region in Malaysia. International Journal of Economics and Finance, 3(2), 166. https://doi.org/10.5539/ijef.v3n2p166

Asgary, A., Azimi, N., \& Anjum, M.I. (2013). Measuring small businesses disaster resiliency: Case of small businesses impacted by the 2010 flood in Pakistan. International Journal of Business Continuity and Risk Management, 4(2), 170187. https://doi.org/10.1504/IJBCRM.2013.056350

Ayala, J.C., \& Manzano, G., (2014). The resilience of the entrepreneur, influence on the success of the business. A longitudinal analysis. Journal of Economic Psychology, 42, 126-135. https://doi.org/10.1016/j.joep.2014.02.004

Bhamra, R., Dani, S., \& Burnard, K. (2011). Resilience: The concept, a literature review and future direction. International Journal of Production Research, 49(18), 5375-5393. https://doi.org/10.1080/00207543.2011.563826

Coyte, R., Ricerri, F., \& Guthrie, J. (2012). The management of knowledge resource in SMEs: An Australian case study. Journal of Knowledge Management, 16(5), 789-807. https://doi.org/10.1108/13673271211262817

Dahles, H., \& Susilowati, T.P. (2015). Business resilience in times of growth and crisis. Annals of Tourism Research, 51, 34-50. https://doi.org/10.1016/j. annals.2015.01.002

Dassi, A., Iborra, M., \& Safon, V., (2015). Beyond path dependence: Explorative orientation, slack resources, and managerial intentionality to internationalize in SMEs. International Business Review, 24(1), 77-88. https://doi.org/10.1016/j. ibusrev.2014.06.003

Duchek, S. (2018). Entrepreneurial resilience: A biographical analysis of successful entrepreneurs. International Entrepreneurship and Management Journal, 14(2), 429-455. https://doi.org/10.1007/s11365-017-0467-2

Dustmann, C., Glitz, A., \& Vogel, T. (2010). Employment, wages, and the economic cycle: Differences between immigrants and natives. European Economic Review, 54(1), 1-17. https://doi.org/10.1016/j.euroecorev.2009.04.004 
Eleventh Malaysia Plan 2016-2020: Anchoring growth on people. Kuala Lumpur: Economic Planning Unit.

Elderly sundry shop owner driven suicide over GST woe. (2015). The Malay Mail Online, 1 June. Retrieved 5 August 2015 from http://www.mmail.com.my/print/malaysia/ elderly-sundry-shop-owner-driven-to-suicide-over-gst-woe.

Fischer, S. (2016). Why are interest rates so low? Causes and implications. Speech at the Economic Club of New York, New York, 17 October.

GST woes trader to attempt suicide. (2015). The Malay Mail Online, 11 May. Retrieved 5 August 2015 from http://www.themalaymailonline.com/malaysia/article/gstwoes-drive-trader-to-attempt-suicide.

Gunasekaran, A., Rai, B.K., \& Griffin, M. (2011). Resilience and competitiveness of small and medium size enterprises: An empirical research. International Journal of Production Research, 49(18), 5489-5509.

Gunderson, L.H. (2000). Ecological resilience - In theory and application. Annual Review of Ecology and Systematics, 31(1), 425-439. https://doi.org/10.1146/annurev. ecolsys.31.1.425

Holling, C.S. (1973). Resilience and stability of ecological systems. Annual Review of Ecology and Systematics, 4(1), 1-23. https://doi.org/10.1146/annurev. es.04.110173.000245

Kang, M. (2016). Supporting women entrepreneurs. The Star Online, 24 October. Retrieved 13 April 2018 from https://www.thestar.com.my/metro/smebiz/ columns/2016/10/24/supporting-women-entrepreneurs/\#iKPHObLGsvpT oQ01.99.

Kundu, S.K., \& Katz, J.A. (2003). Born-international SMEs: B1 level impacts of resources and intentions. Small Business Economics, 20(1), 25-47. https://doi. org/10.1023/A:1020292320170

McInnis-Bowers, C., Parris, D.L., \& Galperin, B.L. (2017). Which came first, the chicken or the egg? Exploring the relationship between entrepreneurship and resilience among the Boruca Indians of Costa Rica. Journal of Enterprising Communities: People and Places in the Global Economy, 11(1), 39-60. https://doi.org/10.1108/ JEC-01-2015-0014

Muscio, A. (2007). The impact of absorptive capacity of SME: Collaboration. Economics of Innovation and New Technology, 16(8), 653-668. https://doi. org/10.1080/10438590600983994

Nandamuri, P.P. (2013). Gender differences on select dimensions of entrepreneurship. IUP Journal of Business Strategy, 10(1), 7-19.

Rohani: Govt to train more women entrepreneurs. (2017). The Star Online, 29 October. Retrieved 13 April 2018 from https:/www.thestar.com.my/news/ nation/2017/10/29/rohani-govt-to-train-more-women-entrepreneurs/\#ellvLF5jgs orJ80i.99.

Torstensson, H., \& Pal, R. (2013). Resilience in textile enterprises and supply chains. Paper presented at the CIRAT 5 - The Fifth International Conference of Applied Research on Textile, Monastir University, Tunisia. 
Williams, N., \& Vorley, T. (2014). Economic resilience and entrepreneurship: Lessons from the Sheffield City Region. Entrepreneurship \& Regional Development, 26(3-4), 257-281. https://doi.org/10.1080/08985626.2014.894129

Weick, K.E., \& Sutcliffe, K.M. (2001). Managing the unexpected-assuring high performance in an age of complexity. San Francisco: Jossey-Bass.

Yusof, A., Alias, R.A., \& Habil, H. (2012). Stereotyping in graduate education: An insight of women's participation in Malaysia. Journal of e-Learning and Higher Education, Article ID 624177, 1-9. https://doi.org/10.5171/2012.624177

Zautra, A.J., Hall, J.S., \& Murray, K.E. (2010). A new definition of health for people and communities. In J.W. Reich, A.J. Zautra, \& J.S. Hall (Eds.), Handbook of adult resilience (pp. 3-29). New York: The Guilford Press. 